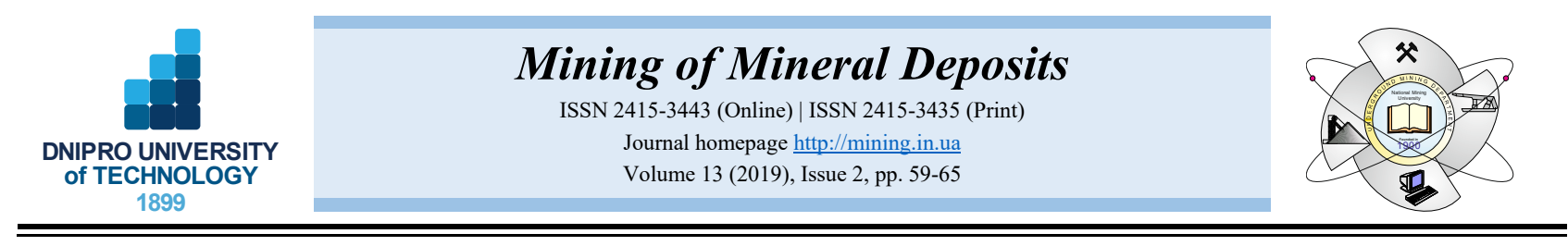

UDC 349:622

https://doi.org/10.33271/mining13.02.059

\title{
STATUTORY AND REGULATORY REQUIREMENTS IN THE PROCESS OF MINERAL MINING IN UKRAINE. REVIEW AND ANALYSIS
}

\author{
R. $\operatorname{Kirin}^{1 *}$

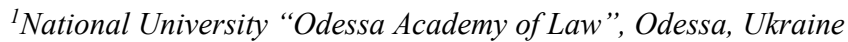 \\ *Corresponding author: e-mail kirinr@ukr.net,tel.+380505716399
}

\begin{abstract}
Purpose. Compliance of statutory and regulatory requirements as for mineral mining, made while subsurface using, mines inspectorating, bringing to responsibility, and creating prerequisites for providing legal guarantees of those who mine the deposits, have been studied.

Methods. The studies are to make sequential comparative analysis of the current statutory and regulatory requirements, determined by the Subsurface Code of Ukraine, and Mining Law of Ukraine concerning mineral mining and identifying a level of their system harmony.

Findings. It has been determined that a complex of the basic requirements for mining of the deposits is formed within corresponding system of subjects of subsoil use at each component of use - inspection - responsibility chain; it is obvious thing that their correspondence has a potential for harmony. New levels of differentiation of the requirements for deposit mining have been determined. It has been mentioned that the requirements for mining involve not only subsoil as a general object; they also concern such objects of the next level as deposits, mine takes, reserves of the minerals, useful components, overburden rocks, mining waste etc.

Originality is to substantiate the available disbalance between statutory and regulatory requirements made for deposit miners, orders by mining and subsoil laws; it is proposed to classify the requirements according to their subjectobject composition as well as to time (stage) of subsoil use.

Practical implications is in the possibility to use the results in the process of lawmaking activities and lawenforcement activities, for studies, connected with further development of a mine law theory, for teaching chapters belonging to legal responsibility in mining, and practices of law enforcement officers and mining enterprises.
\end{abstract}

Keywords: deposit mining, statutory and regulatory requirements, subsoil use, mines inspectorate, legal responsibility

\section{INTRODUCTION}

As an operation schedule, mining of deposits (MD hereinafter) is a system of administrative and technical measures concerning the use of a certain subsoil area to mine minerals (Kubacki \& Kustra, 2009; Bondarenko, Lozynskyi, Sai, \& Anikushyna, 2015; Pivnyak \& Shashenko, 2015). Taking into consideration the act that according to Constitution of Ukraine (Article 13), subsoil is a property of Ukrainian nation; the type of natural resources should be protected by the state and its use should be controlled at the territory of the country. In particular, compliance with governmental regulations should provide effective protection, rational use, and adequate level of technogenic and ecological safety of subsoil during MD (Piwniak, Bondarenko, Salli, Pavlenko, \& Dychkovskiy; Gorova, Pavlychenko, Borysovs'ka, \& Krups'ka, 2013; Petlovanyi, Lozynskyi, Saik, \& Sai, 2018).
In turn, mining law and order should be guaranteed by a number of the state and legal measures - administrative, managerial, regulatory, economic, control and supervisory - which oblige subjects of mining legal relationships to carry out certain duties imposed upon MD subjects (Gorova, Pavlychenko, Kulyna, \& Shkremetko, 2012; Pivniak, Pilov, Pashkevych, \& Shashenko, 2012; Vagonova \& Volosheniuk, 2012).

\subsection{Statement of the problem}

Analysis of the latter aspect is characterized by the extreme topicality for the whole process of deposit mining since if ascertainment of guilt of the subjects is determined as for the violation of subsoil and/or mining law, one of the most efficient legal measures to strengthen mining order and law may be applied, i.e. measures of legal responsibility (Bazaluk \& Blazhevych, 2016; Šimková, Cehlár, \& Pavolová, 2016; Melnyk, 2018). 
Types and order of the latter application for mining law violations is regulated by a number of legal norms inclusive of procedural nature measures foreseen by various law branches. However, the MD subjects, for whom both government and its bodies can apply potentially sanctions to provide law and order in mining, determination of the ratio between lawful MD and law violations in the field, are of the greatest interest.

While analyzing the recent scientific works in the field of object-subject composition of subsoil use, it is necessary to pay attention to fair statement of the authors of the study that obstacles to ensure ecological rights of citizens areas follows: lack of mechanism for community to take part in the processes of significant environmental decisionmaking in the context of legal Ukrainian acts and lack of discussing and submitting of draft bills for the general public which adoption may impact both environment and human health (Kobrynskyi \& Kaminskyi, 2012).

As for subsoil users intended to mine mineral deposits, O.P. Shemiakov proposes to append Article 3 "Rights and obligations of subsoil users" of Subsoil Code of Ukraine (SCU hereinafter) with a separate Article "Insurance in the context of subsoil use to mine mineral deposits" (Shemiakov, 2012).

Referring to legal problems of deposits, it is necessary to mention an idea by O.V. Leonova concerning improvement of legislation on the taxation of mineral prospecting and mining with preferential rates to mine low-gain and depleted mineral deposits (Leonova, 2010).

Among such publications, results of studies, concerning ecological and legislative problems of MD should be mentioned (Hryshchak, Kirin, \& Shashenko, 2012), inclusive of problems with power resources (Gryschak \& Kirin, 2014) as well as general codification problems of Mining Law in Ukraine.

Moreover, conclusions by the authors are rather important as for focusing on the fact that currently Ukraine has no functional structure of Public MD Foundation and the development of an order to enter the deposits in the Foundation register as well as their transfer for use is not stipulated as well (Kirin, 2013; Krasnozhon, \& Liutyi, 2017).

As for the field of state administration and mine inspectorate, attention should be paid to the suggestion by O.Yu. Makarenko concerning further reformation of bodies of regulation and control over relations with subsoil users (Makarenko, 2014) as well as a conclusion by D.I. Koziakov that legislative acts in the field of subsoil use should be coordinated while arranging adequate and perfect mechanisms of legislative control based upon constitutional principles of supremacy of law, equality, and justice followed by the requirements of determination, clearness, understandability, and uniqueness of legal regulations and prohibitions (Koziakov, 2012).

While studying problems of prevention of crimes, connected with violations of laws of subsoil protection or use in Ukraine, I.V. Zdorovylo invites legislator to pay attention to such national problems as violations of laws of subsoil protection or use factoring into the environmental changes resulting from anthropogenic activities (Zdorovylo, 2016); in turn, O.O. Dudorov proposes to eliminate the conflicts being available in terms of legal evaluation of the facts when limits or normative standards of mineral mining are exceeded unlawfully (Dudorov, 2016).

Finally, author of paper (Hladii, 2016) thinks it to be expedient to determine features of use of technogenic deposits, and other technogenic formations at the level of separate legislative act which will contribute to overcoming the deepening crisis in Ukraine; it will also solve a number of problems connected with technogenic soil pollution and formation of mineral raw material base in Ukraine.

Thus, the analysis of recent studies and publications makes it possible to state that the problems of determination of a set of statutory and regulatory requirements for deposit mining, their transformation in the context of legislative statutes within each component of use - supervision - responsibility chain as well as harmony level are still unsolved topical problem of mining and legislative science which is neglected by the integrated research.

\subsection{Purposes of the paper and statement of the problem}

Thus, purpose of the paper is to study correspondence level of statutory and regulatory requirements made for mineral mining in the context of subsoil use, mines inspectorate, bringing to responsibility, and creation conditions to establish legal guarantees concerning protection of rights of deposit miners.

To do that, the paper foresees performance of following task:

- separation of the sets of rights and obligations of subsoil users from the content of the current legislative acts during different mining stages;

- study of the establishment of requirements for differentiated components of resources and subsoil objects;

- analysis of the rights of state mine inspectorate subjects and their correspondence with obligations of deposit miners;

- classification of the types of subsoil law violations in the field of MD in terms of legal protection objects.

Sequence of the study is focused on the comparative analysis of the current statutory and regulatory requirements by SCU and Mining Law of Ukraine (MLU hereinafter) made for MD during different periods, and object-subject composition to determine level of their system harmony.

\section{RESULTS AND DISCUSSIONS}

It seems that determination of harmonization level within control-use - supervision - bringing to legal responsibility chain of activities of correspondent subjects is the fundamental moment to identify the aspect of deposit mining. Transparent and correct formulation of the components and, first of all, in terms of rights obligations categories will favour more unambiguousness while understanding and interpreting rules of mining by means of obliged subjects and authorized ones. However, analysis of a level of legal regulation of requirements for MD by the current legislation makes it possible to consider the group of legal relationships as potentially suitable for reformation of rulemaking process. 
According to Article 23 of the current SCU (Kobrynskyi \& Kaminskyi, 2012), while deposit mining, subsoil users have a right to:

- extract deposits integrally within their areas and perform other activities in accordance with the conditions of a specific license or an agreement on the product distribution (APD hereinafter);

- dispose of the mined minerals if another is not foreseen by legislation or specific license;

- perform conservation of the licensed deposit or its share etc. upon the terms of special permission.

Following obligations of MD subjects should be singled out:

- subsoil use according to the purposes it was allowed;

- completeness of geological analysis, rational and integrated subsoil use and protection;

- provision of safety of people, property, and natural environment (NE hereinafter);

- rehabilitation of land plots, disturbed by subsoil use to the state when they can be applied for their further use in public production etc.

Attention should be paid to the fact that rights and obligations of subsoil users originate when special permission to use subsoil is obtained; if the license is obtained upon APD terms, they originate from the moment the agreement becomes effective if other is not foreseen by the agreement. In this context, subsoil user (investor), who obtained special permission for subsoil use and mine allotment (if it is required) or signed APD, has exclusive right to use subsoil in terms of the permission and APD. Any activity, connected with subsoil use within the mine allotment, can be performed only with the consent of a subsoil user (investor) who obtained it. Such a confirmation or denial may be given during 20 calendar day after corresponding written inquiry was obtained. If no response is obtained during the period, such as agreement is considered as available.

If the investor does not obtain permission from subsoil user on APD for activities within mine allotment granted for such subsoil user to mine minerals exclusive of mine allotments to extract black coal and lignite, anthracite, and iron metallic ores; regardless of such a negative response, the permission may be given by an executive authorized body on the condition that several subsoil users operate within one and the same mine allotment simultaneously, and their activities are not hazardous for human life and health, subsoil and/or industrial objects located within the mine allotment.

The general requirements for $\mathrm{MD}$, established by subsoil law, also append clauses of mine legislation. Among other things, Article 2 of Ukrainian Mine Legislation (Shemiakov, 2012) lists documents giving the right to perform mining operations. Hence, to perform extraction operations, mining enterprise should have:

- special permission for subsoil use;

- mine allotment certificate (exclusive of oil-and-gas bearing subsoil);

- engineering project, approved and agreed properly;

- geological surveying, technical, and accounting and control documentation (i.e. calendar plans of mining development, projects, specifications, schemes).
It should be taken into consideration that the technical documentation should be kept in accordance with the safety rules, operating rules, unified safety rules of blasting operations, and other legal acts. Moreover, Article 51 of SCU also points out that solid, liquid, and gaseous deposits should be mined first in accordance with approved projects and operation schedules, maintenance rules, and subsoil protection rules. Second, subsoil users comfort the maintenance rules, projects, and schedules of MD with authorized executive bodies as for the compliance with subsoil legislation.

The fact, that requirements for MD are differentiated in terms of subject and object composition, and in terms of the subsoil use period (i.e. stage), is another peculiarity of the current legislation. Thus, Article 50 of SCU determines basic requirements for stages of design, construction, and putting into operation of mining objects. Among other things, projects of construction of mining objects should foresee:

- arrangement of surface structures and underground structures to provide more rational and efficient use of the mineral reserves;

- methods of overburden operations during MD, integrated and economically expedient extraction of minerals, and use of components, available in them;

- rational use of overburden rocks while mineral mining;

- storage, and determination of accounting of minerals, which are not used temporarily, waste containing useful components etc.

If the requirements are not met in the process of projection of new mining objects and modernization of the available ones, their putting into operations is prohibited.

It should be noted that even at the stages of subsoil use, one can state that requirements are specified not only referring to the general object, being subsoil in the context of mining, but also referring to its component resources and objects of the following level. That concerns deposits, mine allotments, useful components, overburden rocks, waste etc. Moreover, it is obvious that legislator went beyond only mineral (material) resources and objects being immediate objective in the process of mining but also involved in the correspondent requirements related objects in a mining environment - working force, equipment, NE (i.e. geological resources, land resources, water resources, and atmospheric air). Moreover, not only material resources are meant (for instance, surface structures and underground structure) but also resources of financial and information nature:

- geological and surveying documentation;

- information concerning nation-wide and local taxes and fees, other payments, and concerning production (economic) activities required to provide transparency in the context of mining industries.

Similar requirement targeting is also observed in Article 53 of SCU concerning immediately MD stage:

- use of rational, environmentally friendly mining methods and extraction of useful components as well as selective mining of high-grade deposit sites which results in the loss of minerals; 
- additional mineral prospecting and other geological activities, surveying activities, and maintenance of technical documentation;

- accounting and movement of reserves, losses, degradation of minerals, and established by law reporting to statistical and other state bodies;

- preventing of deposits being under mining from damage as well as neighbouring deposits as a result of mining operations, and preservation of mineral reserves of the deposits being conserved.

In turn, MLU (Article 18) specifies basic requirements for mining. Operational requirements should be singled out:

- use of progressive, safe, and environmentally friendly development and extraction methods;

- constant support of the current mine workings as well as extraction of minerals and their transportation in the state determined by safety rules;

- determination of the system of measures as for safe performance during mining operations;

- rational extraction and use of minerals, subsoil protection etc.

Permissive and normative requirements are also involved:

- mining operations are performed in accordance with the projects and descriptions which were developed and approved in terms of safety rules, operation rules, uniform safety rules for blasting (the projects and descriptions should involve "Emergency protection" chapter);

- in case of actual or forecasted changes in mining and geological (production) conditions, mining operations are ceased until correction and reapproval of the projects and descriptions in accordance with the established procedure;

- projects and descriptions are brought to the notice of employees of mining enterprises in the manner prescribed by the safety rules.

First of all, the considered groups of requirements for mining of deposits are addressed to subsoil users; thus, their comparative analysis with supervisory powers of the relevant subjects is topical. Hence, according to Article 60 of SCU, state supervision and control over geological analysis of subsoil, its use, and protection are intended to provide observance of the appropriate procedure of subsoil use, discharge of obligations regarding subsoil protection established by Ukrainian legislation. The abovementioned concerns all the state bodies, enterprises, institutions, organizations, and citizens. As for the deposit development, State Mining Supervision Authority controls:

- completeness of DM analysis, mining, engineering geological, hydrogeological, and other conditions to extract them; engineering of underground structures and their operation; disposal of harmful substances as well as production waste;

- carrying-out of the requirements concerning subsoil protection while determining raw material conditions and DM;

- correctness of DM;

- complete extraction of the evaluated reserves as well as components, available in them;

- readiness of state paramilitary mining rescue services and organizations as well as operations control to localize and liquidate accident consequences etc.
Not only origination of new requirements for DM subjects, which were not mentioned previously in the above objects of use, but also availability of ambiguous, rather subjective formulations of "deposit mining correctness" type come under notice. Under the conditions of the definition explanation lack, a chance of variability of its interpretation on the part of subjects of mining, and subjects of supervision, multiplies.

In this context, mine supervision body may:

- give obligatory instructions (orders) to eliminate violations of rules and regulations in the process of geological analysis of subsoil, its use, and protection;

- in accordance with the procedures established by Ukrainian legislation, terminate activities connected with subsoil use, if correspondent rules and regulations are violated;

- demand from subsoil users substantiation of writing-off of mineral reserves etc.

Finally, while analyzing of subsoil legislation violations in the field of DM, involving disciplinary, administrative, civil, and criminal responsibility according to Ukrainian legislation, and relying upon provisions of Article 65 of SCU, it is possible to single out following types of the objects of legal protection:

1) mineral resources:

- selective mining of high-grade areas of deposits resulting in excessive losses of mineral reserves;

- damage of minerals which prevents from complete their mining or restricts significantly their further extraction;

- non-compliance with subsoil protection rules, and requirements regarding protection of people, property, and NE against harmful impact of operation connected with subsoil use;

- unauthorized subsoil use;

- excessive losses of mineral degradation in the process of mining;

- violation of the established order concerning developing of mineral occurrence areas;

2) mining and building resources:

- non-fulfillment of the requirements concerning safing of liquidated or conserved mine workings and wells as well as requirements concerning preservation of deposits, mine workings, and wells for a conservation period;

- destruction of observation wells;

3) geological and information resources:

- destruction or damage of survey marks and geodetic monuments;

- unauthorized destruction of survey or geodetic documentation as well as copies of mineral samples required for further geological analysis of subsoil and deposit mining.

\section{CONCLUSIONS}

Thus, the carried-out analysis of a set of regulatory requirements, being a part of the current subsoil and mining legislation of Ukraine make it possible to formulate following conclusions.

Set of the basic requirements for DM is transformed within the corresponding system of responsibilities of subjects of subsoil use to mine minerals; in this context, the requirements are imposed within each component of use - supervision - responsibility chain and their correspondence has obvious potential to harmony. 
Requirements for deposit mining are differentiated:

1) in terms of subject composition:

- subjects regulating legal mining relationships;

- subjects using subsoil (mineral mining);

- subjects of the state mines inspectorate;

- subjects bringing to legal responsibility;

2) in terms of object composition:

- in terms of nature of act - objects of regulation, objects of use, objects of supervision, and law violation objects (subjects);

- in terms of nature of origination - mineral objects (resources), i.e. subsoil, deposits, minerals; spatial objects (mining and building), i.e. mine workings and wells, ground structures and underground structures; information objects (geological and informational), i.e. survey marks, geodetical monuments, surveying and geological documentation, copies of mineral samples;

3 ) in terms of period (stage) of subsoil use, i.e. design, construction, putting into operation of mining object; deposit mining; liquidation (conservation) of a mining object.

The requirements for mining involves not only subsoil as a general object but also objects of the next level (i.e. generic, specific, and immediate - basic, additional, and optional - deposits, mine allotments, mineral reserves, useful components, overburden rocks, waste etc.; in this context, according to the nature of involvement in use, the objects are divided into active (i.e. those, involved in mining) and passive (i.e. those getting to a mining area and may be affected).

\section{ACKNOWLEDGEMENTS}

The results were obtained with no financing or any project support. I express appreciation to reviewers and editors for their valuable comments and recommendations concerning the paper structure improvement. In addition, I express gratitude to Serhii Vasylovych Kivalov, Doctor of Law, President of National University "Odessa Law Academy", people's deputy of Ukraine, a member of the Committee of the Verkhovna Rada of Ukraine on Legal Policy and Justice, Honoured Lawyer of Ukraine, Academician of the Academy of Legal Sciences of Ukraine, Honorary Professor of the Academic Union Oxford for the creation of favourable conditions to carry out the research.

\section{REFERENCES}

Bazaluk, O., \& Blazhevych, T. (2016). The image of an ideal Ukrainian politician. Ukrainian national idea. Future $\mathrm{Hu}$ man Image, (6), 24-30.

Bondarenko, V., Lozynskyi, V., Sai, K., \& Anikushyna, K. (2015). An overview and prospectives of practical application of the biomass gasification technology in Ukraine. New Developments in Mining Engineering 2015: Theoretical and Practical Solutions of Mineral Resources Mining, 27-32. https://doi.org/10.1201/b19901-6

Dudorov, O.O. (2016). Pro vidmezhuvannia nezakonnoho vydobuvannia korysnykh kopalyn vid skladiv administratyvnykh porushen. Materialy Naukovo-Praktychnoi Internet Konferentsii "Novitni Kryminalno-Pravovi Doslidzhennia" (pp. 17-23). Mykolaiv, Ukraina: Ilion.

Gorova, A., Pavlychenko, A., Borysovs'ka, O., \& Krups'ka, L. (2013). The development of methodology for assessment of environmental risk degree in mining regions. Annual Scientific-Technical Collection - Mining of Mineral Deposit, 207-209.

https://doi.org/10.1201/b16354-38

Gorova, A., Pavlychenko, A., Kulyna, S., \& Shkremetko, O. (2012). Ecological problems of post-industrial mining areas. Geomechanical Processes During Underground Mining Proceedings of the School of Underground Mining, 35-40. https://doi.org/10.1201/b13157-7

Gryschak, S., \& Kirin, R. (2014). Legal regime of energy resources of European Union: ecological aspect. Progressive Technologies of Coal, Coalbed Methane, and Ores Mining, 357-360. https://doi.org/10.1201/b17547-61

Hladii, O.V. (2016). Normatyvno-pravove rehuliuvannia administratyvno-pravovoho rezhymu tekhnohennykh rodovyshch v Ukraini. Naukovyi Visnyk Khersonskoho Derzhavnoho Universytetu. Seriia: Yurydychni Nauky, 5(2), 34-38.

Hryshchak, S.V., Kirin, R.S., \& Shashenko, D.O. (2012). Postmining: ekolohichni ta pravovi problemy rozrobky rodovyshch korysnykh kopalyn. Naukovyi Visnyk Dnipropetrovskoho Derzhavnoho Universytetu Vnutrishnikh Sprav, 2(59), 319-324.

Kirin, R.S. (2013). Kodyfikatsiini problemy hirnychoho zakonodavstva. Yurydychna Ukraina, 11(131), 62-66.

Kobrynskyi, V.Yu., \& Kaminskyi, A.I. (2012). Osnovni zasady klasyfikatsii ekolohichnykh prav ta obov'iazkiv liudyny i hromadianyna. Pravo i Suspilstvo, (2), 54-58.

Koziakov, D. (2012). Spivvidnoshennia kontrolnoi kompetentsii orhaniv hirnychoho nahliadu ta heolohichnoho kontroliu u sferi korystuvannia nadramy. Visnyk Natsionalnoi Akademii Prokuratury Ukrainy, (4), 109-113.

Krasnozhon, M.D., \& Liutyi, H.H. (2017). Shchodo pryntsypiv ta polozhen novoi redaktsii Kodeksu Ukrainy pro nadra. Mineralni Resursy Ukrainy, (1), 7-10.

Kubacki, K., \& Kustra, A. (2009). Valuation of mineral deposits in junior mining companies. Deep Mining Challenges, 199-206. https://doi.org/10.1201/noe0415804288.ch21

Leonova, O.V. (2010). Normatyvno-pravove rehuliuvannia vidnosyn nadrokorystuvannia v Ukraini: suchasnyi stan ta perspektyvy vdoskonalennia. Visnyk Akademii Mytnoi Sluzhby Ukrainy. Seriia: Pravo, (2), 70-78.

Makarenko, O.Yu. (2014). Spetsyfika derzhavnoho rehuliuvannia vidnosyn korystuvannia nadramy: orhany zahalnoi, spetsialnoi kompetentsii. Naukovyi Visnyk Dnipropetrovskoho Derzhavnoho Universytetu Vnutrishnikh Sprav, (1), 85-94.

Melnyk, T. (2018). Ukraine and its future in a globalised international community. Ukrainian Policymaker, (3), 17-28. https://doi.org/10.29202/up/3/3

Petlovanyi, M.V., Lozynskyi, V.H., Saik, P.B., \& Sai, K.S. (2018). Modern experience of low-coal seams underground mining in Ukraine. International Journal of Mining Science and Technology, 28(6), 917-923. https://doi.org/10.1016/j.ijmst.2018.05.014

Pivniak, H.H., Pilov, P.I., Pashkevych, M.S., \& Shashenko, D.O. (2012). Synchro-mining: civilized solution of problems of mining regions' sustainable operation. Naukovyi Visnyk Natsionalnoho Hirnychoho Universytetu, (3), 131-138.

Pivnyak, G.G., \& Shashenko, O.M. (2015). Innovations and safety for coal mines in Ukraine. Naukovyi Visnyk Natsionalnoho Hirnychoho Universytetu, (6), 118-121.

Piwniak, G.G., Bondarenko, V.I., Salli, V.I., Pavlenko, I.I., \& Dychkovskiy, R.O. (2007). Limits to economic viability of extraction of thin coal seams in Ukraine. Technical, Technological and Economic Aspects of Thin-Seams Coal Mining International Mining Forum 2007, 129-132. https://doi.org/10.1201/noe0415436700.ch16 
Shemiakov, O.P. (2012). Derzhavna okhorona prav pryrodokorystuvachiv. Visnyk Luhanskoho Derzhavnoho Universytetu Vnutrishnikh Sprav im. E.O. Didorenka, (4), 225-233.

Šimková, Z., Cehlár, M., \& Pavolová, H. (2016). Strategy of point out relevance of responsible exploitation of mineral resources. Acta Montanistica Slovaca, 21(3), 208-216.

Vagonova, O.G., \& Volosheniuk, V.V. (2012). Mining enterprises' economic strategies as derivatives of nature ma- nagement in the system of social relations. Naukovyi Visnyk Natsionalnoho Hirnychoho Universytetu, (2), 127-134.

Zdorovylo, I.V. (2016). Aktualni pytannia zapobihannia zlochynam, pov'iazanym iz porushenniam pravyl okhorony abo vykorystannia nadr, v Ukraini. Pytannia Borotby $z i$ Zlochynnistiu, (31), 183-196.

\section{НОРМАТИВНО-ПРАВОВІ ВИМОГИ ПРИ РОЗРОБЦІ РОДОВИЩ КОРИСНИХ КОПАЛИН В УКРАЇНІ. ОГЛЯД ТА АНАЛІЗ}

\section{Р. Кірін}

Мета. Дослідження рівня відповідності нормативно-правових вимог, що висуваються до розробки родовищ корисних копалин, при здійсненні користування надрами, гірничому нагляді та притягненні до відповідальності, а також створення передумов для встановлення юридичних гарантій охорони прав розробників родовищ.

Методика. Дослідження полягає у послідовному порівняльному аналізі чинних нормативно-правових вимог, встановлених Кодексом України про надра та Гірничим законом України, до розробки родовищ корисних копалин і виявленні рівня їх системної узгодженості.

Результати. Встановлено, що сукупність основних вимог до розробки родовищ трансформується у відповідній системі обов'язків суб'єктів користування надрами на кожній складовій ланки “користування - нагляд відповідальність”, а їх кореспонденція, очевидно, має потенціал до збалансованості. Встановлені нові рівні диференціації вимог до розробки родовищ. Відзначено, що вимоги до розробки охоплюють не лише надра, як загальний об'єкт, а й об'єкти наступного рівня - родовища, гірничі відводи, запаси корисних копалин, корисні компоненти, розкривні породи, відходи виробництва тощо.

Наукова новизна полягає в обгрунтуванні наявного дисбалансу між нормативно-правовими вимогами, що висуваються до розробників родовищ, приписами гірничого та надрового законодавства, а самі вимоги запропоновано класифікувати за суб’єктно-об’єктним складом та часом (стадією) користування надрами.

Практична значимість полягає в можливості використання результатів у процесі правотворчої та правозастосовчої діяльності, у наукових дослідженнях, пов'язаних із подальшою розробкою теорії гірничого права, у навчальному процесі, у ході викладання розділів, що відносяться до юридичної відповідальності в гірничій справі, у практичній роботі працівників правоохоронних органів та гірничих підприємств.

Ключові слова: розробка родовищ, нормативно-правові вимоги, користування надрами, гірничий нагляд, юридична відповідальність

\section{НОРМАТИВНО-ПРАВОВЫЕ ТРЕБОВАНИЯ ПРИ РАЗРАБОТКЕ МЕСТОРОЖДЕНИЙ ПОЛЕЗНЫХ ИСКОПАЕМЫХ В УКРАИНЕ. ОБЗОР И АНАЛИЗ}

\section{Р. Кирин}

Цель. Исследование уровня соответствия нормативно-правовых требований, предъявляемых к разработке месторождений полезных ископаемых, при осуществлении пользования недрами, горном надзоре и привлечении к ответственности, а также создание предпосылок для установления юридических гарантий охраны прав разработчиков месторождений.

Методика. Исследование заключается в последовательном сравнительном анализе действующих нормативно-правовых требований, установленных Кодексом Украины о недрах и Горным законом Украины, к разработке месторождений полезных ископаемых и выявлении уровня их системной согласованности.

Результаты. Установлено, что совокупность основных требований к разработке месторождений трансформируется в соответствующей системе обязанностей субъектов пользования недрами на каждой составляющей звена “пользование - надзор - ответственность”, а их корреспонденция, очевидно, имеет потенциал к сбалансированности. Установлены новые уровни дифференциации требований к разработке месторождений. Отмечено, что требования к разработке охватывают не только недра, как общий объект, но и объекты следующего уровня месторождения, горные отводы, запасы полезных ископаемых, полезные компоненты, вскрышные породы, отходы производства и т.п.

Научная новизна заключается в обосновании имеющегося дисбаланса между нормативно-правовыми требованиями, предъявляемыми к разработчикам месторождений, предписаниями горного и недрового законодательства, а сами требования предложено классифицировать по субъектно-объектному составу и времени (стадией) пользования недрами.

Практическая значимость заключается в возможности использования результатов в процессе правотворческой и правоприменительной деятельности, в научных исследованиях, связанных с дальнейшей разработкой теории горного права, в учебном процессе, в ходе изложения разделов, относящихся к юридической ответственности в горном деле, в практической работе сотрудников правоохранительных органов и горных предприятий.

Ключевые слова: разработка месторождений, нормативно-правовые требования, пользование недрами, горный надзор, юридическая ответственность 


\section{ARTICLE INFO}

Received: 20 December 2018

Accepted: 22 April 2019

Available online: 6 May 2019

\section{ABOUT AUTHORS}

Roman Kirin, Doctor of Juridical Sciences, Professor of the Department of Agricultural, Land and Environmental Law, National University "Odessa Academy of Law", 23 Fontanska doroha St, 65009, Odessa, Ukraine. E-mail: kirinr@ukr.net 